\title{
A INTERPRETAÇÃO CONSTITUCIONAL DO PREQUESTIONAMENTO
}

\author{
Ângelo Soares Castilhos ${ }^{1}$
}

\section{Introdução}

Como bem exprime CÂNDIDO RANGEL DINAMARCO, "o recurso extraordinário era, como é, ligado aos objetivos dos recursos em geral, ou seja, (a) preservar a ordem jurídica em sua autoridade e unidade de interpretação, mas também (b) servir de canal para as insatisfações e inconformismos e, portanto, meio instrumental da justiça." ${ }^{2}$ Assim, além da precípua função de conservar a unidade e a autoridade do direito federal pátrio ${ }^{3}$, os recursos de alçada extraordinária são, também, meios de realização da justiça, através da correta aplicação do Direito positivo.

É justamente aqui, nesse ponto, que reside o que talvez seja uma das grandes celeumas do Direito Processual brasileiro: o prequestionamento como óbice ao conhecimento e/ou provimento de recursos extraordinários e de recursos especiais (inclusive eleitorais). Todo processo de aplicação exige, como consentâneo lógico, a interpretação. O processo de "subjetivar a regra objetiva"4, contudo, encontra, na esfera excepcional, uma limitação cognitiva inexistente em grau de apelação: a matéria objeto da insurgência deve estar prequestionada.

Ocorre que o prequestionamento, mesmo que decorridos 125 anos de sua incorporação ao ordenamento jurídico pátrio, ainda suscita inúmeras controvérsias, tanto na doutrina quanto na jurisprudência. Introduzido no regramento do antigo recurso inominado para o Supremo Tribunal Federal - primeiro no art. 59, $\S 1^{\circ}$, do Decreto n. 510, de 23 de junho de 1890, e, depois, no art. $9^{\circ}$, II, parágrafo único, do Decreto n. 848, de 11 de outubro de 1890, que tinha por base a Lei Judiciária dos Estados Unidos da América do Norte (Judiciary Act), de $1789^{5}$-, consagrou-se no Direito brasileiro como elemento imprescindível ao conhecimento do recurso extraordinário ${ }^{6}$, também na conformação dada à insurgência pela Constituição de 1891. Sua exigência permaneceu ao longo dos anos, perdurando na vigência de todas as Constituições, inclusive da atual, de 1988, conforme majoritário entendimento.

Ora, se o processo "possui uma estrutura e uma função" e o "problema da estrutura consiste em saber o que é o processo; o problema da função consiste em saber para que serve o processo" ", deve-se ter em vista sua teleologia, em uma visão voltada aos direitos fundamentais pro- 
cessuais. A interpretação do prequestionamento, a partir do art. 102, III, "a", e do art. 105, III, "a", ambos da Constituição de 1988 (e igualmente do art. 121, $\S 4^{\circ}, \mathrm{I}$, por construção jurisprudencial analógica e pela intermediação legislativa do art. 276, I, do Código Eleitoral) deve ser sistemática, não isolada, ganhando especial relevo o conteúdo positivo (e metapositivo) do art. $5^{\circ}$, caput, seus incisos e parágrafos, da Magna Carta.

\section{Prequestionamento: explícito e implícito}

A classificação adotada pela maior parte da doutrina e por toda a jurisprudência dos Tribunais Superiores é a que divide o prequestionamento em explícito (quando há a menção expressa à norma constitucional ou infraconstitucional no julgamento a quo) e implícito (quando se depreende do julgado, apesar da não indicação do dispositivo de modo expresso, a norma objeto de debate e de decisão).

A constatação de CARLOS MAXIMILIANO, que, frise-se, é perfeita, deixa claro que a questão já é antiga:

Não é mistér que explìcitamente neguem a existência de um dispositivo; basta a negação implícita, isto é, que procedam ou decidam como se êle não vigorasse, deixem de o aplicar. Assim acontece, por exemplo, quando o juiz aplica outra norma, ou guarda silêncio sôbre a lei invocada, ou sôbre a questão de Direito suscitada. ${ }^{8}$

Apesar da aparente simplicidade com que foram apresentados os conceitos acima, a prática das lides forenses aponta para um sinuoso e controverso caminho: o Supremo Tribunal Federal, o Superior Tribunal de Justiça e o Tribunal Superior Eleitoral possuem divergentes entendimentos acerca da admissibilidade de uma e de outra espécie.

O posicionamento do Superior Tribunal de Justiça, no que é acompanhado pelo Tribunal Superior Eleitoral, afirma a cognoscibilidade dos recursos excepcionais amparados no debate implícito:

AGRAVO REGIMENTAL. AGRAVO EM RECURSO ESPECIAL. PREQUESTIONAMENTO.

FALTA DE MENÇÃO NO ACÓRDÃO ACERCA DA MATÉRIA CONTIDA NO DISPOSITIVO LEGAL. QUESTÃO RESOLVIDA NA ORIGEM COM BASE EM LEI ESTADUAL. AGRAVO IMPROVIDO.

1. O prequestionamento, como requisito de admissibilidade para a abertura da instância especial, é admitido não só na forma explícita, 
mas, também, na forma implícita, o que não dispensa, no entanto, o necessário debate acerca da matéria controvertida.

2. A simples indicação de preceito legal, sem que sobre ele tenha havido a emissão de um juízo de valor no acórdão recorrido, não configura prequestionamento implícito apto a inaugurar a instância especial.

3. O Tribunal de origem decidiu a lide com base no estabelecido no Decreto Estadual n. 21.123/83. Imprescindível seria a análise da lei local para o deslinde da controvérsia. Incidência do óbice contido no enunciado da Súmula 280 do STF, por analogia ("Por ofensa a direito local não cabe recurso extraordinário").

4. Agravo regimental desprovido. ${ }^{9}$

ELEIÇÕES 2008. AGRAVO REGIMENTAL. AGRAVO DE INSTRUMENTO. AÇÃO DE INVESTIGAÇÃO JUDICIAL ELEITORAL. ABUSO DO PODER ECONÔMICO. CAPTAÇÃO ILÍCITADE SUFRÁGIO. MANUTENÇÃO DA DECISÃO.

1. A alegada violação do art. 30-A da Lei n. 9.504/1997 não foi debatida na Corte Regional. Ausência de prequestionamento. Súmulas nos 282 e 356/STF.

2. "Para se entender pelo prequestionamento implícito, é necessário que a questão alegada tenha sido efetivamente debatida e julgada." (AgR-REspe n. 3993524-43/AM, rel. Min. Marcelo Ribeiro, julgado em 31.3.2011)

3. Agravo regimental desprovido. ${ }^{10}$

Porém, a majoritária jurisprudência do Supremo Tribunal Federal inclina-se em sentido oposto, admitindo apenas a modalidade explícita do prequestionamento:

RECURSO EXTRAORDINÁRIO COM AGRAVO (LEI N. 12.322/2010) ALEGADA VIOLAÇÃO A PRECEITOS CONSTITUCIONAIS - AUSÊNCIA DE PREQUESTIONAMENTO - OFENSA INDIRETAÀ CONSTITUIÇÃO - CONTENCIOSO DE MERA LEGALIDADE - RECURSO IMPROVIDO.

- A ausência de efetiva apreciação do litígio constitucional, por parte do Tribunal de que emanou o acórdão impugnado, não autoriza ante a falta de prequestionamento explícito da controvérsia jurídica a utilização do recurso extraordinário.

- A situação de ofensa meramente reflexa ao texto constitucional, quando ocorrente, não basta, só por si, para viabilizar o acesso à via recursal extraordinária. ${ }^{11}$ 
Desse modo, entende-se que o posicionamento dos Tribunais Superiores (de Justiça e Eleitoral) esteja em mais consonância com a Constituição, uma vez que o prequestionamento, como instituto de Direito Processual, basicamente, não deveria obstaculizar a realização da função constitucional dos Altos Pretórios, pois, como observa, com correção, FRANCISCO CAVALCANTI PONTES DE MIRANDA, "note-se, portanto, que, onde a Justiça negou incidência ou procedeu, julgando, como se negasse a incidência, necessàriamente se deu ensejo à interposição do recurso extraordinário. Porque deixar de aplicar regra jurídica é explìcitamente ou implìcitamente negar-Ihe incidência." ${ }^{.12}$

\section{A Súmula n. 282 do Supremo Tribunal Federal}

A "Súmula da Jurisprudência Dominante do Supremo Tribunal Federal" foi a grande inovação do sistema recursal extraordinário brasileiro durante a vigência da Carta Constitucional de 1946. E, dentre as primeiras a serem editadas, em 16 de dezembro de 1963, uma possui especial relevo para esse trabalho: a Súmula n. 282, segundo a qual "é inadmissível o recurso extraordinário, quando não ventilada, na decisão recorrida, a questão federal suscitada."

O enunciado teve como origem precedentes do Supremo Tribunal Federal ${ }^{13}$ que, deve-se confessar, muito pouco esclarecem sobre o instituto do prequestionamento em si: a ênfase, em praticamente todas, é o não conhecimento do recurso extraordinário pela falta de oposição de embargos declaratórios perante o Tribunal a quo. Além disso, os acórdãos são de um laconismo acentuado. Nesse contexto, destaca-se, dentre tais julgados, o Recurso Extraordinário n. 53.740, do extinto Estado da Guanabara, assim ementado: "Matéria não prequestionada pela instância local. Recurso Extraordinário não conhecido."14

Do voto do Ministro RIBEIRO DA COSTA, extrai-se: "Contesta, entretanto, o recorrido, com veemência, aquela alegação, mas não cabe, na instância extraordinária, o exame de matéria cuja apreciação e julgamento não se verifique no contexto da decisão recorrida."

Malgrado seja um verbete seriamente combatido por parte da doutrina, a posição majoritária admite, amplamente, a incidência do enunciado n. 282 da Súmula do Pretório Excelso aos processos da competência recursal extraordinária dos Tribunais Superiores, a exemplo do Ministro EDUARDO RIBEIRO DE OLIVEIRA: 
A Súmula 282 do Supremo Tribunal Federal consagrou o verdadeiro sentido do que se há de reputar necessário para que se tenha presente o prequestionamento. A questão deverá ter sido ventilada na decisão recorrida. Embora talvez melhor se dissesse que haveria de ter sido decidida no julgamento recorrido, importa a circunstância de que não se fez menção a prévio debate. A referência a 'questão federal suscitada' é de entender-se como a que o foi no recurso extraordinário. Revela o decidido, tenha ou não sido a matéria anteriormente levantada por alguma das partes. ${ }^{15}$

E, sem dúvida, o papel institucionalizado dos verbetes sumulares dos diversos tribunais pátrios possui protagonismo na vida forense. Em termos de lógica jurídica, eles cumprem uma função importantíssima: colocar em evidência matérias insistentemente tratadas pelos pretórios, dizendo o "direito jurisprudenciado".

Nesse sentido, há renomada doutrina a defender o trabalho do aplicador na positivação do Direito, afirmando estar no trabalho de interpretação, não no standard legislativo, a positivação da norma. Disserta JUAREZ FREITAS:

Preferível afirmar que o intérprete constitucional, de certo jeito, positiva o sistema, derradeiramente. Fora de dúvida, o juiz (não o legislador) é quem culmina o processo de positivação jurídica. Eis o motivo pelo qual, como salientado em capítulos antecedentes, a jurisprudência, mesmo no sistema romanístico, deve ser reconhecida e proclamada, no mínimo, como fonte material mais significativa, fenômeno nítido quando se aceita a vinculação, forte ou débil, de qualquer interpretação. ${ }^{16}$

Portanto, somente a correta utilização de enunciados, como, in casu, o n. 282, é capaz de propiciar um bom funcionamento do sistema judiciário, uma vez que a cristalização das posições sedimentadas pelos colegiados é, evidentemente, um instrumento de estabilização da jurisprudência, em consonância com o art. 926 do Novo Código de Processo Civil.

\section{Sobre os brocardos iura novit curia e da mihi factum, tibi dabo ius}

Há uma séria divisão, como também não poderia deixar de ser, acerca da aplicação dos brocardos latinos iura novit curia e da mihi factum, tibi dabo ius. A doutrina, em maioria, afirma não ser possível a sua aplicação nos graus extraordinários, assim como a jurisprudência do Supremo Tribunal Federal. Há, no entanto, no Superior Tribunal de Justiça, diver- 
gência quanto ao tema, considerando a aplicabilidade dos mencionados brocardos ao recurso especial.

O Ministro FRANCISCO CLÁUDIO DE ALMEIDASANTOS sempre foi uma voz ativa, enquanto compunha o Superior Tribunal de Justiça, contra a aplicação das máximas latinas supramencionadas:

Não vigoram, para os recursos constitucionais, os conhecidos brocardos jura novit curia e da mihi factum, dabo tibi jus, próprios da jurisdição absoluta e de não-superposição, ou seja, dos juízos singulares e dos Tribunais de Apelação que apreciam os fatos e aplicam o direito. Os Tribunais Superiores, não constituindo uma terceira ou, muito menos, quarta instância, aplicam, apenas, o direito invocado ou somente solucionam o dissídio apontado pelas partes. ${ }^{17}$

Em sentido diametralmente oposto, é a doutrina do incomparável FRANCISCO CAVALCANTI PONTES DE MIRANDA, para quem o aforismo iura novit curia é parte indissociável do sistema recursal brasileiro:

Aliás, em sistema jurídico que tem o princípio lura novit curia, seria absurdo que não se desse recurso extraordinário contra a decisão do juiz que, sem alegação contrária, deixou de aplicar regra jurídica federal, ou aplicou regra jurídica local, não referida, por entender não ser contrária à Constituição de 1946, ou a lei federal, a despeito de não se lhe haver 'contestado' a validade. ${ }^{18}$

Já o eminente processualista ARAKEN DE ASSIS traz à lume uma concepção, poder-se-ia dizer, eclética em relação ao tema: o Tribunal Superior está adstrito, em graus de admissibilidade e julgamento das questões, ao Direito invocado; porém, internamente a cada uma delas, poderia haver a livre aplicação do Direito à espécie:

À afloração dos tipos criados na Constituição basta que as questões federal e constitucional se encontrem individualizadas no pronunciamento impugnado. É verdade que, nos recursos especial e extraordinário, a fundamentação vinculada afasta a pertinência automática e ampla do aforismo iura novit curia: tanto a admissibilidade quanto o julgamento do mérito desses recursos se realizam no âmbito estrito das questões recorridas; internamente a cada uma delas, todavia, competindo ao Tribunal Superior julgar a causa devolvida, parece lícito aplicar a lei ou a Constituição, livremente, à espécie. ${ }^{19}$

Contudo, o Supremo Tribunal Federal, conforme sua jurisprudência dominante, nega a possibilidade da utilização dos aforismos em grau de recurso extraordinário, v. g.:

- Recurso extraordinário. - O recurso extraordinário, alegando que o acórdão recorrido ofendeu os princípios constitucionais do devido 
processo legal, da ampla defesa, da acessibilidade das partes ao Poder Judiciário e da prestação jurisdicional, além de não explicitar quais os incisos do artigo $5^{\circ}$ da Constituição que prevêem esses princípios, o que é indispensável em se tratando de recurso extraordinário em que não vigora o princípio "Iura novit curia", versou questões constitucionais que não foram ventiladas no acórdão recorrido, nem foram - como teriam de sê-lo ainda quando questões originárias do aresto recorrido - objeto de embargos de declaração, faltandoIhes, pois, se pudesse ser ultrapassado o óbice acima referido, o indispensável prequestionamento (súmulas 282 e 356). Recurso extraordinário não conhecido. ${ }^{20}$

No entanto, impende salientar que há uma incongruência no estudo da jurisprudência relativa aos recursos excepcionais, sobretudo por ocasião do cotejamento deste julgado, que é uma amostragem da corrente majoritária na Suprema Corte, com a Súmula n. 456, também do Supremo Tribunal Federal, que dispõe: "O Supremo Tribunal Federal, conhecendo do recurso extraordinário, julgará a causa, aplicando o direito a espécie."

Verifica-se que esse enunciado revelaria a aplicabilidade dos brocardos latinos em tela também na atuação jurisdicional do Supremo Tribunal Federal, do Superior Tribunal de Justiça e do Tribunal Superior Eleitoral, tendo, inclusive, tido expressamente adotada sua tese no seguinte acórdão, que julgou embargos de divergência (em última instância: uniformização de jurisprudência) no Superior Tribunal de Justiça:

ERESP - CONSTITUCIONAL - PROCESSUAL CIVIL - RECURSO ESPECIAL - PREQUESTIONAMENTO.

Prequestionamento é pressuposto do Recurso Especial; representa o tema decidido na instância originária e trazido pelo Recorrente ao Superior Tribunal de Justiça. Desnecessário indicar o artigo de lei incidente na espécie. Narra mihi factum dabo tibi ius. ${ }^{21}$

Portanto, a par da dissidência doutrinária e jurisprudencial, é correta a afirmação de que ao juiz é inafastável o dever de conhecimento e de aplicação das normas jurídicas vigentes (e válidas), mesmo que o juiz em tela seja um ministro do Supremo Tribunal Federal, do Superior Tribunal de Justiça ou do Tribunal Superior Eleitoral. No entanto, entende-se que isso somente seja possível naquelas situações em que incidir um ou outro verbete: ou é aplicável a Súmula n. 282 e, estando ausente o prequestionamento, o recurso é inadmissível; ou é aplicável a Súmula n. 456 e, uma vez admitida a insurgência, o direito em tese pode ser reenquadrado, em vista de um contexto de clareza da situação fática delineada pelo acórdão local. 
Tal dever funcional, pois, de conferir à causa o desfecho desejado pelo ordenamento jurídico abstratamente considerado, emana da exigência constitucional da motivação das decisões judiciais (art. 93, IX, da Constituição) em combinação com: o art. 102, III, que confere ao Supremo Tribunal Federal o papel de "guardião da Constituição"; o art. 105, III, que confere ao Superior Tribunal de Justiça as funções uniformizadoras e de preservação da autoridade do direito federal infraconstitucional pátrio em relação à Justiça Comum (Federal e Estadual), e o art. 121, § $4^{\circ}$ (por construção jurisprudencial e pela intermediação legislativa do art. 276, I, do Código Eleitoral), que confere ao Tribunal Superior Eleitoral as funções uniformizadoras e de preservação da autoridade do direito federal pátrio (constitucional e infraconstitucional) em relação à Justiça Eleitoral.

\section{As questões de ordem pública e o prequestionamento}

As questões de ordem pública encontram, no que diz respeito ao momento de sua arguição, uma disciplina específica no Código de Processo Civil:

Art. $267, \S 3^{\circ} \mathrm{O}$ juiz conhecerá de ofício, em qualquer tempo e grau de jurisdição, enquanto não proferida a sentença de mérito, da matéria constante dos ns. IV, V e Vl; todavia, o réu que a não alegar, na primeira oportunidade em que Ihe caiba falar nos autos, responderá pelas custas de retardamento.

Importante frisar que tal dispositivo restou novamente contemplado no Novo Código de Processo Civil: "Art. 485, § $3^{\circ} \mathrm{O}$ juiz conhecerá de ofício da matéria constante dos incisos IV, V, VI e IX, em qualquer tempo e grau de jurisdição, enquanto não ocorrer o trânsito em julgado."

A prerrogativa de o órgão julgador conhecer, ex officio, das questões de ordem pública tem seu alcance perfeitamente delineado pela doutrina e pela jurisprudência no que se refere aos graus ordinários de jurisdição, em que é plenamente aplicável. A controvérsia, porém, inicia quando a discussão gira em torno da jurisdição extraordinária lato sensu: há um conflito entre a possibilidade do conhecimento de ofício pelo juiz e o prequestionamento.

NELSON NERY JUNIOR afirma que a vedação ao conhecimento espontâneo pelo julgador, em sede extraordinária e especial, advém de uma interpretação conforme a Constituição do art. 267, § $3^{\circ}$, do Código de Processo Civil:

A exigência é constitucional, de modo que a lei ordinária (CPC e leis federais extravagantes) não pode dispensá-la. Assim, quando o CPC 
267 , § $3^{\circ}$, e 301 , $\S 4^{\circ}$, ao tratarem das questões de ordem pública determinam que o juiz ou tribunal deve conhecê-las ex officio, a qualquer tempo e grau de jurisdição, devemos entender grau 'ordinário' de jurisdição, pois só assim a interpretação dessas normas do CPC estará conforme a Constituição (verfassungsmässige Auslegung von Gesetzen). ${ }^{22}$

Porém, parcela considerável da doutrina adota uma concepção mais branda em relação ao tema, admitindo o conhecimento das questões de ordem pública em grau excepcional de jurisdição. É o caso de RODOLFO DE CAMARGO MANCUSO:

De fato, parece-nos que em questões de ordem pública que, por sua natureza, não precluem e são suscitáveis em qualquer tempo e grau de jurisdição, além de serem cognocíveis de ofício, e, bem assim em tema de condições da ação e de pressupostos - positivos e negativos - de existência e validade da relação jurídica processual (CPC, art. $267, \S 3^{\circ}$ ), o quesito do prequestionamento pode ter-se por inexigível, até em homenagem à lógica do processo e à ordem jurídica justa. ${ }^{23}$

O Superior Tribunal de Justiça, de modo bastante rigoroso, não vem admitindo o conhecimento das questões de ordem pública cujo prequestionamento não se faça presente, $v$. $g$.:

AGRAVO REGIMENTAL. AGRAVO EM RECURSO ESPECIAL. AGRAVO DE INSTRUMENTO. MULTA COMINATÓRIA. VALOR. PREQUESTIONAMENTO. AUSÊNCIA.

ARTIGO 526 DO CPC. NÃO CUMPRIMENTO. LITIGÂNCIA DE MÁ-FÉ. REEXAME DE MATÉRIAFÁTICADALIDE. SÚMULA7/STJ. NÃO PROVIMENTO.

1. Se as questões trazidas à discussão foram dirimidas, pelo Tribunal de origem, de forma suficientemente ampla, fundamentada e sem omissões deve ser afastada a alegada violação ao art. 535 do Código de Processo Civil.

2. Não tendo havido o prequestionamento dos temas ventilados nas razões do recurso especial, incide o enunciado 211 da Súmula do STJ.

3. O exame no âmbito do recurso especial de questões de ordem pública não prescinde seja atendido o requisito do prequestionamento. Precedentes.

4. Inviável o recurso especial cuja análise impõe reexame do contexto fático-probatório da lide (Súmula 7 do STJ).

5. Agravo regimental a que se nega provimento. ${ }^{24}$ 
Também o Tribunal Superior Eleitoral trata da temática com o mesmo entendimento:

ELEIÇÕES 2010. AGRAVO REGIMENTAL EM RECURSO ESPECIAL. NEGATIVA DE SEGUIMENTO. REPRESENTAÇÃO. OUTDOOR. PROPAGANDA IRREGULAR. PREQUESTIONAMENTO. AUSÊNCIA. RAZÕES RECURSAIS QUE NÃO AFASTAM FUNDAMENTO SUFICIENTE DA DECISÃO AGRAVADA. INCIDÊNCIA DA SÚMULA 182 DO STJ. DESPROVIMENTO.

1. É inviável o agravo regimental que não traz argumento novo que se sobreponha aos fundamentos lançados na decisão agravada (Súmula 182 do STJ).

2. É pacífico o entendimento do Tribunal Superior Eleitoral de que, em âmbito de recurso especial, impõe-se o requisito do prequestionamento, ainda que se cuide de questão de ordem pública.

3. Agravo regimental desprovido. ${ }^{25}$

Portanto, a matéria é extremamente controversa, mas, ainda assim, predomina a vedação ao conhecimento das questões sem a prévia discussão nas instâncias inferiores.

\section{Sobre a inconstitucionalidade do enunciado da súmula}

Há duas correntes que defendem a inconstitucionalidade da Súmula n. 282 do Supremo Tribunal Federal. Contudo, uma e outra apresentam prismas bem diferenciados: a primeira afirma a inconstitucionalidade do prequestionamento, sem ressalvas; a segunda diz que 0 prequestionamento é inconstitucional quando o Tribunal ad quem exige a explicitação do artigo de lei ou da Constituição no acórdão atacado. Verse-á ambas a partir de agora.

A tese da inconstitucionalidade total da Súmula n. 282 do Supremo Tribunal Federal possui como principal protagonista o grande jurisconsulto GALENO VELLINHO DE LACERDA. Em um parecer jurídico publicado, o eminente professor assinala na conclusão do escrito:

Em face do exposto, a simples exigência do prequestionamento é inconstitucional, por ofensa direta aos preceitos imperativos dos arts. 102, III, $a$, ou 105, III, $a, b$ e $c$, da Carta Magna Vigente, que não subordinam a esse requisito ou condição o direito subjetivo ao uso, seja do recurso extraordinário, seja do recurso especial, conforme a hipótese. ${ }^{26}$ 
Também FRANCISCO CAVALCANTI PONTES DE MIRANDA fazia o mesmo juízo crítico acerca da validade do prequestionamento perante a Constituição desde a Carta de 1946:

Se o tribunal ou juiz, esquivando-se à questão, permite que o seu silêncio sôbre ela tenhas as conseqüências de atitude prevista em qualquer dos casos do art. 101, III, cabe o recurso extraordinário (Supremo Tribunal Federal, 16 de junho de 1920). Outrossim, quando, dissimulando o seu pronunciamento, recorre ao sofisma de se tratar de mera interpretação (19 de dezembro de 1923), ou, pràticamente, procede como se prevê no pressuposto do recurso extraordinário, no tocante à sua atitude (19 de janeiro de 1927). A Constituição cogitou das espécies em que a Justiça inferior diz, claramente, como se conduziu na resposta aos problemas que lhe foram postos; se essa, por negligência ou por má-fé, contraria o pedido, sem usar de têrmos positivos, mas de tal modo que assim seja o seu julgamento, êsse procedimento não pode ter a conseqüência de prejudicar as partes." ${ }^{27}$

No entanto, as palavras mais surpreendentes acerca do assunto vêm do Ministro CARLOS MÁRIO DA SILVA VELLOSO, em texto escrito pouco tempo após a Assembleia Constituinte, em que ele admite a não recepção, pela Constituição de 1988, do instituto do prequestionamento:

Seriam possíveis os óbices jurisprudenciais, como, por exemplo, a exigência do prequestionamento, a que a jurisprudência do Supremo Tribunal deu especial ênfase, como se pode ver dos enunciados das Súmulas 282, 317 e 356?

Contou-me um famoso advogado que presenciara, num julgamento ocorrido no Supremo Tribunal, uma ocorrência que demonstrou a grande importância que o alto pretório emprestava ao prequestionamento: o Min. Baleeiro apontava uma inconstitucionalidade de lei, demonstrava que a Constituição estava sendo violada pela lei ordinária, e um seu colega, um ilustre juiz, dizia: Ministro, não podemos conhecer dessa questão, porque não houve o prequestionamento. E, o Supremo Tribunal assim decidiu, vale dizer, não declarou a apontada inconstitucionalidade.

[...]

O prequestionamento, sob o pálio da Constituição de 1988, não terá vez, ao que penso. É que o constituinte de 1988 quis alargar o raio de ação do recurso especial. Isto está evidente no texto constitucional. Ademais, de regra, o prequestionamento põe-se de forma implícita quando a decisão contraria ou nega vigência à lei federal. ${ }^{28}$ 
Contudo, a declaração de incompatibilidade entre o texto constitucional (Carta de 1967-1969, ressalta-se) e a súmula em comento está fora de cogitação, ao menos para o Supremo Tribunal Federal, desde que o Tribunal Pleno julgou o Agravo Regimental nos Embargos de Divergência no Recurso Extraordinário 96.802-4/RJ, tendo como Relator o Ministro ALFREDO BUZAID, cuja ementa categoriza:

1. Constitucional. O prequestionamento supõe não apenas que, na petição de recurso, a parte vencida mencione os cânones constitucionais violados, mas que a matéria tenha sido ventilada e discutida no Tribunal a quo, onde ficaram vulnerados.

2. O recurso extraordinário é um meio de impugnação, cujas condições e motivos estão expressamente designados no art. 119 da Constituição e só tem lugar nos casos que especifica. O prequestionamento é uma das condições de admissibilidade do recurso extraordinário.

3. Inteligência do prequestionamento. Direito comparado.

4. Não servem aos embargos de divergência os acórdãos já invocados para demonstrá-los, mas rejeitados como não dissidente no julgamento do recurso extraordinário (art. 331 do Regimento Interno do Supremo Tribunal Federal)." 29

A segunda corrente, por outro lado, possui uma visão diferenciada do problema: só seria inconstitucional o prequestionamento à medida que fosse exigida a transcrição da norma (textualmente ou a referência ao número do artigo) no acórdão atacado. HÉLIO RUBENS BATISTA RIBEIRO COSTA faz uma feliz síntese dessa corrente de pensamento:

No entanto, algumas distorções ocorrem quanto ao correto alcance do verbete sumular em comentário, na medida em que alguns recursos excepcionais deixam de ter deferido o processamento em razão da ausência de prequestionamento quando a ele se empresta uma conceituação equivocada.

O verbete n. 282 da súmula da jurisprudência dominante do Supremo Tribunal Federal, que não é inconstitucional, exige tão-somente o debate do conteúdo normativo, vale dizer, a análise da matéria jurídica constitucional ou federal pela decisão recorrida sem fazer qualquer exigência, entretanto, à citação expressa do dispositivo legal ou constitucional violado: não precisa constar do acórdão, muito menos a parte mencionar no curso da ação, o número do artigo da Constituição ou de lei federal para que sejam admissíveis os recursos excepcionais.

Esta exigência, que algumas decisões insistem seja cumprida para a admissão dos recursos extraordinários, revela-se inconstitucional 
por ferir o direito de amplo acesso e ilimitado contraditório, porque, se o acórdão tratou da matéria jurídica, desnecessário se revela a escrita expressa do dispositivo legal que veicula aquele comando normativo.

Em outras palavras, o prequestionamento é da norma, não do número do artigo da Constituição ou de lei federal que a veicula. ${ }^{30}$

Pode-se concluir, então, que, para este último posicionamento, o excesso de formalismo com que o Supremo Tribunal Federal trata a questão do prequestionamento se mostra inconstitucional, indo contra justamente o que há de mais importante na sua atuação: a realização da justiça através do acesso do jurisdicionado à prestação jurisdicional completa.

\section{Prequestionamento e instrumentalidade do processo}

Sob a contemporânea perspectiva do Direito Processual constitucionalizado, não mais se pode admitir que o procedimento tenha prevalência sobre a substância. A não realização do direito material em virtude de fatores exclusivamente processuais é algo indesejável, ainda mais em um sistema constitucional que prevê, como direitos e garantias fundamentais, em matéria processual, o princípio da inafastabilidade de apreciação das questões pelo Poder Judiciário (acesso à justiça - art. $5^{\circ}$, $X X X V)$, o princípio do devido processo legal (art. $5^{\circ}$, LIV) e o princípio da fundamentação das decisões do Poder Judiciário (art. 93, IX).

Nessa esteira, a atuação da Suprema Corte e dos Tribunais Superiores ganha especial importância, uma vez que a guarda da Constituição e da legislação infraconstitucional federal são missões conferidas constitucionalmente (artigos 102, III, 105, III, e 121, § $4^{\circ}$ ). Portanto, tais funções institucionais não poderiam, sob argumento de cunho exclusivamente formalístico-processual, serem excluídas, sob pena de se negar ao cidadão duas garantias primordiais: o acesso ao Poder Judiciário, que não significa apenas que a "porta de entrada" da jurisdição deva estar aberta ${ }^{31}$, mas também que, ao final do processo, tenha sido realizada a efetiva e inafastável apreciação da lide pelo órgão julgador; e o devido processo legal, que deve atuar, sempre, em conformidade com o Direito, diante do que torna-se incabível um formalismo excessivo que admita a preponderância do instrumento sobre o direito material em si.

Então, se "a garantia do devido processo legal constitui a expressão constitucional do formalismo processual: o informalismo excessivo (em 
que as partes perigam sossobrar ao arbítrio e ao poder do Estado) e o excesso de formalismo (em que o conteúdo - o direito material e a justiça - corre o risco de periclitar por razões de forma) estabelecem os seus limites extremos"32, e se "no caso de normas polissémicas ou plurisignificativas deve dar-se preferência à interpretação que lhe dê um sentido em conformidade com a constituição"33, não há como explicar o desvalor por vezes conferido aos jurisdicionados, dando-se ao prequestionamento uma concepção formalista extremada, que vai de encontro com a Constituição de 1988.

Por mais que se admita que o prequestionamento, hoje, seja inclusive uma necessidade dos Tribunais Superiores, como maneira de suprimir o exame de recursos manifestamente incabíveis, dado o excessivo volume de feitos que, todos os meses, lá aportam, não se pode esquecer que a busca do Poder Judiciário pela eficiência deve conciliar a manutenção das garantias processuais com as necessidades do sistema judiciário de obter resultados (ou seja, o maior número possível de causas julgadas), como bem frisa CARLOS ALBERTO ALVARO DE OLIVEIRA:

À vista do exposto, pode-se concluir que garantismo e eficiência devem ser postos em relação de adequada proporcionalidade, por meio de uma delicada escolha dos fins a atingir e uma atenta valoração dos interesses a tutelar. $E$ o que interessa realmente é que nessa difícil obra de ponderação sejam os problemas da justiça solucionados num plano diverso e mais alto do que o puramente formal dos procedimentos e transferidos ao plano concernente ao interesse humano objeto dos procedimentos: um processo assim na medida do homem, posto realmente ao serviço daqueles que pedem justiça.

Em suma, com a ponderação desses dois valores fundamentais efetividade e segurança jurídica - visa-se idealmente a alcançar um processo tendencialmente justo.

Observe-se, finalmente, à vista do caráter essencialmente principiológico dos direitos fundamentais, que só se pode determinar o que se entende por processo justo levando-se em conta as circunstâncias peculiares do caso. ${ }^{34}$

Portanto, leciona CÂNDIDO RANGEL DINAMARCO, "não basta afirmar o caráter instrumental do processo sem praticá-lo, ou seja, sem extrair desse princípio fundamental e da sua afirmação os desdobramentos teóricos e práticos convenientes. Pretende-se que em torno do princípio da instrumentalidade do processo se estabeleça um novo método de pensamento do processualista e do profissional do foro"35. 


\section{Prequestionamento e direitos fundamentais processuais}

A Constituição da República de 1988 trouxe, de forma muito clara e incisiva, para o ordenamento jurídico brasileiro, a supremacia dos direitos fundamentais. Com isso, ganha destaque o papel primordial do Estado (lato sensu) de, além de assegurar a realização e o cumprimento dos direitos fundamentais pelos particulares, ele próprio concretizá-los em sua atuação cotidiana.

O Estado, uma vez considerada a ordem natural das coisas - um Estado Democrático de Direito -, não é apenas o grande fiscalizador da implementação dos direitos humanos, mas sim o grande protagonista da sua efetivação, jamais devendo esquecer que ele mesmo está irremediavelmente vinculado a eles. Esta vinculação, inclusive, é mais abrangente que o próprio conceito de constitucionalidade das leis: a conformidade com a Carta Magna deve estar em cada ato estatal. ${ }^{36}$

Diante dessa realidade jurídica, constitucionalmente dirigida à realização dos direitos fundamentais, não poderia o Poder Judiciário, logicamente, estar fora de sintonia com tais preceitos. Isso porque "aos tribunais cabe a tarefa clássica da defesa dos direitos e interesses legalmente protegidos dos cidadãos (CRP, art. 205\%2). Os tribunais, porém, não estão apenas ao serviço da defesa de direitos fundamentais; eles próprios, como órgãos do poder público, devem considerar-se vinculados pelos direitos fundamentais. Esta vinculação dos tribunais efectiva-se ou concretiza-se: (1) através do processo aplicado no exercício da função jurisdicional ou (2) através da determinação e direcção das decisões jurisdicionais pelos direitos fundamentais materiais." ${ }^{37}$

Conclui-se, pois, que toda a atuação dos Tribunais, seja qual for a instância ou grau, deve ser orientada pela consonância com os mandamentos principiológicos da Carta Magna. Desse modo, os julgados, os regimentos internos, os despachos, as súmulas, enfim, toda a tramitação processual está constitucionalmente referenciada. Por isso, também a jurisprudência, enquanto conjunto de decisões homogêneas e convergentes, está vinculada aos direitos fundamentais.

Nessa esteira, o prequestionamento, como espécie do formalismo processual, deve ser interpretado e aplicado em conformidade, primordialmente, com três princípios basilares do Direito Processual, insculpidos em normas constitucionais institutivas de direitos fundamentais processuais dos jurisdicionados: o princípio da inafastabilidade de apreciação pelo Poder Judiciário, ou do acesso à Justiça (art. $5^{\circ}, \mathrm{XXXV)}$; o princípio 
do devido processo legal (art. 50, LIV); e o princípio da fundamentação das decisões judiciais (art. 93, IX). Em uma visão essencialmente comprometida com tais direitos, sendo o jurisdicionado, salvo melhor juízo, o fim último e a razão primeira de ser do processo judicial, a sua supremacia é elemento-chave para uma completa e adequada prestação jurisdicional.

Ora, mais que qualquer órgão do Poder Público, deveria ser o Supremo Tribunal Federal, como guardião da Constituição da República ${ }^{38}$, o maior interessado na salvaguarda da inteireza e da correção de interpretação e de aplicação do texto máximo do ordenamento jurídico pátrio. Por isso, o óbice meramente formal do prequestionamento explícito, assentado basicamente na jurisprudência (em leitura restritiva do Enunciado n. 282 da Súmula de Jurisprudência Dominante), não é, em última análise, a que mais se coaduna com os direitos fundamentais processuais.

Por isso, entra em contradição o próprio Supremo Tribunal Federal em suas manifestações jurisdicionais, uma vez que afirma a obrigação de o Estado-juiz prestar com completude a jurisdição, mas, em contrapartida, aplica incontinenti, a exigência do prequestionamento explícito. Observe-se a seguinte ementa:

$[\ldots]$ PRESTAÇÃO JURISDICIONAL - INTEIREZA.

A ordem jurídico-constitucional assegura aos cidadãos o acesso ao Judiciário em concepção maior. Engloba a entrega da prestação jurisdicional da forma mais completa e convincente possível. Omisso o provimento judicial e, em que pese a interposição de embargos declaratórios, persistindo o vício na arte de proceder, forçoso é assentar a configuração da nulidade. Isso ocorre diante da recusa do órgão julgador em emitir entendimento explícito sobre a valia, ou não, de aresto indicado, como paradigma, para efeito de conhecimento do recurso de revista - artigo 896 da Consolidação das Leis do Trabalho. ${ }^{39}$

Por isso, a aplicação do requisito do prequestionamento, objetivando cumprir os ditames determinados pelos direitos humanos procedimentais, passa pela filtragem da interpretação constitucionalmente referenciada. É o que preconiza JUAREZ FREITAS, no terceiro de seus dez preceitos, para uma interpretação sistemática da Constituição:

Terceiro Preceito: Toda exegese sistemática constitucional tem o dever de garantir a maior tutela jurisdicional possível 
Oportuno aduzir, como terceira diretriz ilustrativa em matéria de interpretação constitucional sistemática, que o intérprete constitucional precisa considerar, ampliativamente, o inafastável poder-dever de prestar a tutela jurisdicional, de sorte a garantir, ao máximo, o acesso legítimo à sua prestação. Em outras palavras, trata-se de extrair os maiores e melhores efeitos da adoção, entre nós, da cláusula pétrea da jurisdição única, donde segue a intangibilidade do disposto no art. 5, XXXV da Constituição Federal. Tal 'monopólio' do exercício da jurisdição em sentido próprio não comporta flexibilização ablativa. Se ameaçado ou violado o núcleo deste direito fundamental, estar-se-á perante clara e insofismável ofensa aos incisos III e IV do $\S 4 .{ }^{\circ}$ do art. 60 da Constituição. Portanto, são os juízes que determinam, em instância definitiva, qual o conteúdo, por exemplo, dos direitos e garantias individuais que não podem sequer tender a ser abolidos por emenda. [...] A rigor, não existe ato absolutamente insindicável. ${ }^{40}$

Assim, mesmo que haja a resistência ao instituto, sua existência e aplicação hoje são indiscutíveis. Os Tribunais Superiores, inclusive, podese dizer, dependem dele para manter uma regular abreviação da carga de trabalho à frente dos processos, fulminando um sem número de recursos pela falta do requisito essencial do prequestionamento. Assim, salvo meIhor juízo, a posição do Superior Tribunal de Justiça, ainda que possa não ser a melhor, é a que mais coaduna com os princípios constitucionais orientadores do Direito Processual, exercendo um formalismo moderado, através da exigência apenas do prequestionamento implícito. ${ }^{41}$

\section{Conclusão}

Da pesquisa acerca de intersecções consideradas de extrema relevância entre o tema central e o Direito Constitucional, o Direito Processual, a doutrina e a jurisprudência pátrios, surgiu a grande quaestio iuris do presente trabalho: a compatibilidade e as possibilidades do prequestionamento ante a Constituição da República Federativa do Brasil, de 5 de outubro de 1988. A conclusão a que se chega é a de que os Tribunais do Brasil ainda não colocaram em consonância com a Lei Maior suas máquinas judiciárias de modo geral e irrestrito.

O Ministro ATHOS GUSMÃO CARNEIRO, em passagem ilustrativa, escreve que "o Min. Néri da Silveira, do Supremo Tribunal Federal, em mais de uma oportunidade referiu que 'a questão é tão importante que mesmo em matéria sumulada não se dispensa o prequestionamento' (in RTJ 98/ 754; Al 110.452-0; RE 99.230; RE 99.930); ou: 'a falta de prequestionamento opportuno tempore, torna inviável o $\mathrm{RE}$, qualquer que 
seja a matéria federal e sua importância ou relevância' (Al 110.239, apud Antônio Carlos Amaral Leão, RT 650/236)." ${ }^{42}$ Como pode ser depreendido, a rigidez no trato do prequestionamento é a regra nas Cortes Superiores, com especial relevo para o Supremo Tribunal Federal.

Na longa evolução da cultura processual-procedimental do Poder Judiciário nacional, ainda não se chegou ao estágio ideal, em que "A eficácia jurídica imediata que hoje se reconhece aos direitos fundamentais traduz a mutação operada nas relações entre a lei e os direitos do cidadão: de direitos fundamentais apenas no âmbito da lei transitou-se para a ideia de lei apenas no âmbito dos direitos fundamentais." ${ }^{43}$

Portanto, é mister, sim, em nome dos direitos humanos procedimentais, que se fundamente o labor judicante dos órgãos do Poder Judiciário em uma premissa essencial: as questões, sejam elas de fato ou de direito, uma vez postas em juízo, nas instâncias ordinárias, devem vincular o julgador, impondo-lhe a obrigação de expedir uma manifestação jurídica sobre elas, nos moldes do que determina 0 art. 489, § $1^{\circ}$, do Novo Código de Processo Civil. Somente desse modo o prequestionamento estará a serviço de sua real finalidade: extirpar das pautas dos Tribunais Superiores recursos manifestamente infundados, que ventilem argumentos inovadores ou despropositados. Como hodiernamente aplicado, o prequestionamento é óbice não só a este tipo de insurgência, mas também àquelas que buscam a reforma ou a cassação de decisões cuja motivação deixa a desejar, ou seja, violadoras do art. 93, IX, da Constituição de 1988.

Assim, a rigidez do sistema ${ }^{44}$ deve estar concentrada na efetivação do princípio fundamental do acesso à justiça (art. $5^{\circ}, \mathrm{XXXV}$, da Constituição de 1988), estruturante do Estado de Direito ${ }^{45}$, o qual só pode ser considerado completamente realizado se houver o respeito ao devido processo legal (art. $5^{\circ}$, LIV, da Lex Maxima), o qual, por sua vez, só é possível se as Cortes locais nortearem-se pelo princípio da fundamentação das decisões judiciais (art. 93, IX, da Carta Magna).

\section{Referências}

ASSIS, Araken de. Prequestionamento e embargos de declaração. Revista Jurídica, Porto Alegre, Notadez Informação, v. 288, pp. 5/27, out. 2001.

CANOTILHO, José Joaquim Gomes. Direito Constitucional. 6. ed. Coimbra: Almedina, 1996.

Coimbra, 2001.

Constituição dirigente e vinculação do legislador. 2. ed. Coimbra: 
CARNEIRO, Athos Gusmão. Recurso especial, agravos e agravo interno. 3. ed. Rio de Janeiro: Forense, 2003.

COSTA, Hélio Rubens Batista Ribeiro. Breves considerações sobre o prequestionamento. Revista do Instituto dos Advogados de São Paulo, São Paulo, Revista dos Tribunais, n. 6, pp. 258/270, 2000.

COUTURE, Eduardo Jose. Introdução ao estudo do processo civil. Traduzido por: Vitor Mozart Russomano. 3. ed. Rio de Janeiro: Forense, 1998.

DINAMARCO, Cândido Rangel. A instrumentalidade do processo. 11. ed. São Paulo: Malheiros, 2003.

Superior Tribunal de Justiça e acesso à ordem jurídica justa. In: Recursos no Superior Tribunal de Justiça. TEIXEIRA, Sálvio de Figueiredo (Coord.). São Paulo: Saraiva, 1991. pp. 249/258.

FREITAS, Juarez. A interpretação sistemática do Direito. 3. ed. São Paulo: Malheiros, 2002. 2004

A interpretação sistemática do Direito. 4. ed. São Paulo: Malheiros,

LACERDA, Galeno Vellinho de. Considerações críticas sobre o prequestionamento. Cadernos de Direito Constitucional e Ciência Política, São Paulo, Revista dos Tribunais, v. 29, pp. 251/264, 1999.

LEAL, Victor Nunes. Passado e futuro da súmula do S.T.F. Revista da Associação dos Juízes do Rio Grande do Sul, Porto Alegre, AJURIS, n. 25, pp. 46/67, jul. 1982.

LESSA, Pedro. Do Poder Judiciário. Ed. fac-similar. Brasília: Senado Federal, 2003.

MIRANDA, Jorge. Contributo para uma teoria da inconstitucionalidade. Reimpressão. Coimbra: Coimbra Editora, 1996.

OLIVEIRA, Carlos Alberto Alvaro de. O processo civil na perspectiva dos direitos fundamentais. Revista da Faculdade de Direito da Universidade Federal do Rio Grande do Sul, Porto Alegre, UFRGS, v. 22, pp. 31/42, set. 2002.

Do formalismo no processo civil. 2. ed. São Paulo: Saraiva, 2003.

OLIVEIRA, Eduardo Andrade Ribeiro de. Prequestionamento. Coletânea de Julgados e Momentos Jurídicos no TFR e STJ, Brasília, v. 38, pp. 167/179, 2002.

PEREIRA DOS SANTOS, Carlos Maximiliano. Comentários à Constituição brasileira de 1946. 5. ed. Rio de Janeiro: Freitas Bastos, 1954. v. II.

Bastos, 1947.

Hermenêutica e aplicação do Direito. 6. ed. Rio de Janeiro: Freitas 
PONTES DE MIRANDA, Francisco Cavalcanti. Comentários à Constituição de 1946. 3. ed. Rio de Janeiro: Borsoi, 1960. t. III. 1960. t. IV.

Comentários à Constituição de 1946. 3. ed. Rio de Janeiro: Borsoi,

SANTOS, Francisco Cláudio de Almeida. Recurso especial - visão geral. In: Recursos no Superior Tribunal de Justiça. TEIXEIRA, Sálvio de Figueiredo (Coord.). São Paulo: Saraiva, 1991. pp. 91/107.

VELLOSO, Carlos Mário da Silva. Superior Tribunal de Justiça e a Constituição. In: Revista de Direito Público, n. 90, pp. 79/97, abr./jun. 1989.

\section{Notas}

${ }^{1}$ Analista Judiciário do TRE-SC, removido para o TRE-RS. Bacharel em Ciências Jurídicas e Sociais pela UFRGS. Especialista em Direito Constitucional pela FMP/RS. Pós-graduando em Direito Processual Civil pelo Grupo Verbo Jurídico.

2 DINAMARCO, Cândido Rangel. Superior Tribunal de Justiça e acesso à ordem jurídica justa. In: Recursos no Superior Tribunal de Justiça. TEIXEIRA, Sálvio de Figueiredo (Coord.). São Paulo: Saraiva, 1991. p. 252.

${ }^{3}$ A doutrina é maciça nessa direção: "O recurso extraordinário, cujas espécies são precisadas no art. 101, III, penetrou no direito brasileiro com a República federativa. Prende-se êle, como galhos e troncos à raiz, à necessidade de se assegurar, em todo o território e em tôdas as dimensões do ambiente jurídico nacional, a realização uniforme da lei federal." (PONTES DE MIRANDA, Francisco Cavalcanti. Comentários à Constituição de 1946. 3. ed. Rio de Janeiro: Borsoi, 1960. t. III, p. 272). "'Com adotar o sistema do Direito escrito e codificado, o Estado moderno indicou a sua preferência pela segurança e homogeneidade, em detrimento da plasticidade, característica do regime consuetudinário. Para tirar destas vantagens o melhor partido possível, era fôrça manter a unidade da jurisprudência e o respeito à lei. Para êste fim, se tornou indispensável uma Corte Suprema.' Acórdãos do STF, n. 2.795 (22.12.1909), 2.962 (26.10.1910) e 252 (16.12.1911)" (PEREIRA DOS SANTOS, Carlos Maximiliano. Comentários à Constituição brasileira de 1946. 5. ed. Rio de Janeiro: Freitas Bastos, 1954. v. II, p. 359)

${ }^{4}$ PEREIRA DOS SANTOS, Carlos Maximiliano. Hermenêutica e aplicação do Direito. 6. ed. Rio de Janeiro: Freitas Bastos, 1947. p. 29.

${ }^{5}$ Cf. LESSA, Pedro. Do Poder Judiciário. Ed. fac-similar. Brasília: Senado Federal, 2003. p. 104; e PONTES DE MIRANDA, Francisco Cavalcanti. Comentários à Constituição de 1946. 3. ed. Rio de Janeiro: Borsoi, 1960. t. III, p. 272 ; etc. 
${ }^{6}$ A origem da denominação está no primeiro Regimento Interno do Supremo Tribunal Federal, de 8 de agosto de 1891, sendo, depois, introduzida no ordenamento jurídico pela Lei n. 221, de 20 de novembro de 1894, no art. 24 (PEDRO LESSA, op. cit., p. 103). A sua adoção no texto constitucional deu-se apenas em 1934, no art. 76, n. 2, III.

${ }^{7}$ COUTURE, Eduardo Jose. Introdução ao estudo do processo civil. Trad. Vitor Mozart Russomano. 3. ed. Rio de Janeiro: Forense, 1998. p. 37.

${ }^{8}$ Comentários..., p. 369.

${ }^{9}$ Agravo Regimental no Agravo em Recurso Especial n. 101.507/SP. Relator Ministro Olindo Menezes (Desembargador Convocado do TRF $1^{\text {a }}$ Região). Primeira Turma. Brasília, 20 de agosto de 2015. Diário de Justiça Eletrônico, 31 ago. 2015.

${ }^{10}$ Agravo Regimental em Agravo de Instrumento n. 271730. Relator Ministro Gilmar Ferreira Mendes. Tribunal Pleno. Brasília, 27 de novembro de 2014. Diário de Justiça Eletrônico, Tomo 240, 22 dez. 2014. pp. 16/17.

${ }^{11}$ Agravo Regimental no Agravo em Recurso Extraordinário. Relator Ministro Celso de Mello. Segunda Turma. Brasília, $1^{\circ}$ de setembro de 2015. Diário da Justiça Eletrônico, 194, 29 set. 2015.

${ }^{12}$ PONTES DE MIRANDA, Francisco Cavalcanti. Comentários à Constituição de 1946. 3. ed. Rio de Janeiro: Borsoi, 1960. t. III, p. 328.

${ }^{13}$ Recurso Extraordinário n. 42.662, do Estado de São Paulo, Relator Ministro Victor Nunes Leal, julgado em 25.10.1961; Recurso Extraordinário n. 48.815, do Estado do Maranhão, Relator Ministro Gonçalves de Oliveira, julgado em 29.11.1961; Recurso Extraordinário n. 49.075, do Estado de São Paulo, Relator Ministro Victor Nunes Leal, julgado em 14.11.1962; Embargos no Recurso Extraordinário n. 46.682, do Estado de São Paulo, Relator Ministro Victor Nunes Leal, julgado em 14.12.1962; Recurso Extraordinário n. 50.157, do Estado da Guanabara, Relator Ministro Victor Nunes Leal, julgado em 15.5.1963; Agravo de Instrumento n. 28.938, do Estado da Guanabara, Relator Ministro Victor Nunes Leal, julgado em 22.5.1963; Recurso Extraordinário n. 48.165, do Estado de São Paulo, Relator Ministro Luiz Gallotti, julgado em 25.9.1963; e Recurso Extraordinário n. 53.740, do Estado da Guanabara, Relator Ministro Ribeiro da Costa, julgado em 4.9.1963, conforme informação inserida, no site do Supremo Tribunal Federal, (http://www.stf.jus.br/portal/jurisprudencia/ listarJurisprudencia.asp?s1=282.NUME.\%20NAO\%20S.FLSV.\&base=baseSumulas). Acesso em 04.10.2015.

${ }^{14}$ Recurso Extraordinário 53.740/GB. Relator Ministro Ribeiro da Costa. Brasília, 4 de setembro de 1963. Diário da Justiça, 5 set.1963, p. 2.891.

${ }^{15}$ OLIVEIRA, Eduardo Andrade Ribeiro de. Prequestionamento. In: Coletânea de Julgados e Momentos Jurídicos no TFR e STJ, Brasília, 2002, v. 38, p. 174. 
${ }^{16}$ FREITAS, Juarez. A interpretação sistemática do Direito. 4. ed. São Paulo: Malheiros, 2004. p. 191.

${ }^{17}$ SANTOS, Francisco Cláudio de Almeida. Recurso Especial - Visão geral. In: Recursos no Superior Tribunal de Justiça. TEIXEIRA, Sálvio de Figueiredo [Coord.]. São Paulo: Saraiva, 1991. p. 103.

${ }^{18}$ Comentários à Constituição..., t. III, p. 330.

${ }^{19}$ ASSIS, Araken de. Prequestionamento e embargos de declaração. In: Revista Jurídica, Porto Alegre, Notadez Informação, v. 288, outubro/2001, pp. 15/16.

${ }^{20}$ Recurso Extraordinário 262.797/SP. Relator Ministro José Carlos Moreira Alves. Primeira Turma. Brasília, 18 de abril de 2000. Diário da Justiça, 16 jun. 2000, p. 41.

${ }^{21}$ Embargos de Divergência em Recurso Especial n. 144.844/RS. Relator Ministro Luiz Vicente Cernicchiaro. Corte Especial. Brasília, 03 de fevereiro de 1999. Diário da Justiça, 28 jun.1999, p. 42. No mesmo sentido, o Agravo Regimental no Recurso Especial n. 1455713/SC, Relator Ministro Mauro Campbell Marques. Terceira Turma. Brasília, 18 de novembro de 2014. Diário da Justiça Eletrônico, 24 nov. 2014: "PROCESSUAL CIVIL. LIMITES DA LIDE. INTERPRETAÇÃO LÓGICO-SISTEMÁTICADO PEDIDO. JULGAMENTO EXTRAPETITA. INOCORRÊNCIA. 1. Não há error in procedendo no provimento jurisdicional firmado após compreensão lógico-sistemática do pedido, entendido como "aquilo que se pretende com a instauração da demanda" (AgRg no REsp 1155859/MT, Rel. Ministro MARCO BUZZI, QUARTA TURMA, DJe 4.2.2014), eis que "o pedido não é apenas o que foi requerido em um capítulo específico ao final da petição inicial, mas, sim, o que se pretende com a instauração da demanda, sendo extraído de interpretação lógicosistemática da inicial como um todo" (AgRg no REsp 1284020/SP, Rel. Ministro HUMBERTO MARTINS, SEGUNDA TURMA, DJe 6.3.2014). 2. "(...) a obrigatória adstrição do julgador ao pedido expressamente formulado pelo autor pode ser mitigada em observância dos brocardos da 'mihi factum dabo tibi ius' (dá-me os fatos que te darei o direito) e 'iura novit curia' (o juiz é quem conhece o direito)". Precedente: REsp 1197476/BA, Rel. Ministro RICARDO VILLAS BÔAS CUEVA, TERCEIRA TURMA, DJe 10.10.2014. 3. Agravo regimental não provido."

${ }^{22}$ NERY JÚNIOR, Nelson. Teoria geral dos recursos. 6.ed. São Paulo: Revista dos Tribunais, p. 292.

${ }^{23}$ MANCUSO, Rodolfo de Camargo. Recurso extraordinário e recurso especial. 7. ed. São Paulo: Revista dos Tribunais, 2001. p. 216.

${ }^{24}$ Agravo Regimental no Agravo em Recurso Especial n. 201.433/SP. Relatora Ministra Maria Isabel Gallotti. Quarta Turma. Brasília, 17 de setembro de 2015. Diário da Justiça Eletrônico 25 set. 2015. 
${ }^{25}$ Agravo Regimental em Recurso Especial Eleitoral n. 781613. Acórdão de 12.12.2013, Relatora Ministra Laurita Hilário Vaz. Brasília, 12 de dezembro de 2013. Diário de Justiça Eletrônico, Tomo 23, 3 fev. 2014, pp. 317/318.

${ }^{26}$ LACERDA, Galeno Vellinho de. Considerações críticas sobre o prequestionamento. In: Cadernos de Direito Constitucional e Ciência Política, São Paulo, Revista dos Tribunais, v. 29, 1999, p. 264.

${ }^{27}$ PONTES DE MIRANDA, Francisco Cavalcanti. Comentários à Constituição de 1946. 3. ed. Rio de Janeiro: Borsoi, 1960. t. IV, p. 316.

${ }^{28}$ VELLOSO, Carlos Mário da Silva. Superior Tribunal de Justiça e a Constituição. In: Revista de Direito Público, n. 90, abril/junho de 1989, p. 93. Artigo publicado também na Revista de Direito Administrativo, São Paulo, Revista dos Tribunais, v. 175, janeiro/março de 1989, pp. 9/27.

${ }^{29}$ Agravo Regimental nos Embargos de Divergência no Recurso Extraordinário 96.802-4/RJ. Relator Ministro Alfredo Buzaid. Tribunal Pleno. Brasília, 12 de maio de 1983. Revista Trimestral de Jurisprudência do Supremo Tribunal Federal, Brasília, v. 109, t. I, pp. 299/304.

${ }^{30}$ COSTA, Hélio Rubens Batista Ribeiro. Breves considerações sobre o prequestionamento. In: Revista do Instituto dos Advogados de São Paulo, São Paulo, Revista dos Tribunais, n. 06, 2000, p. 263.

${ }^{31}$ É a doutrina de CARLOS ALBERTO ALVARO DE OLIVEIRA: "É claro que não basta apenas abrir a porta de entrada do Poder Judiciário, mas prestar jurisdição tanto quanto possível e eficiente, efetiva e justa, mediante um processo sem dilações ou formalismos excessivos. Exatamente a perspectiva constitucional do processo veio a contribuir para afastar o processo do plano das construções conceituais e meramente técnicas e inseri-lo na realidade política e social. Tal se mostra particularmente adequado no que diz respeito ao formalismo excessivo, pois sua solução exige o exame do conflito dialético entre duas exigências contrapostas, mas igualmente dignas de proteção, asseguradas constitucionalmente: de um lado, a aspiração de um rito munido de um sistema possivelmente amplo e articulado de garantias "formais" e, de outro, o desejo de dispor de um mecanismo processual eficiente e funcional." (ALVARO DE OLIVEIRA, Carlos Alberto. O Processo Civil na Perspectiva dos Direitos Fundamentais. In: Revista da Faculdade de Direito da Universidade Federal do Rio Grande do Sul, Porto Alegre, UFRGS, v. 22, setembro/2002, p. 40)

${ }^{32}$ ALVARO DE OLIVEIRA, Carlos Alberto. Do formalismo no processo civil. 2. ed. São Paulo: Saraiva, 2003. p. 86.

${ }^{33}$ CANOTILHO, José Joaquim Gomes. Direito Constitucional. 6. ed. Coimbra: Almedina, 1996. p. 229. 
${ }^{34}$ O Processo Civil..., p. 42.

${ }^{35}$ DINAMARCO, Cândido Rangel. A Instrumentalidade do processo. 11. ed. São Paulo: Malheiros, 2003. p. 378.

${ }^{36}$ Anota CANOTILHO: "O princípio da conformidade dos actos do Estado com a Constituição é mais amplo que o princípio da constitucionalidade das leis. Ele exige desde logo conformidade intrínseca e formal de todos os actos dos poderes públicos (em sentido amplo: Estado, poderes autónomos, entidades públicas) com a constituição. Mesmo os actos não normativos directamente densificadores de momentos políticos da Constituição - actos políticos devem sujeitar-se aos parâmetros constitucionais e ao controlo (político ou jurídico) de conformidade (cfs. art. 3.\%/3). Finalmente, o princípio da constitucionalidade não é apenas uma exigência de actos que não violem positivamente a constituição; também a omissão inconstitucional, por falta de cumprimento das imposições constitucionais ou das ordens de legislar, constitui uma violação do princípio da constitucionalidade (cfr. art. 283)." (Direito Constitucional..., pp. 360/361)

${ }^{37}$ JOSÉ JOAQUIM GOMES CANOTILHO, Direito Constitucional..., p. 586.

${ }^{38}$ Art. 102, caput, da Lei Maior.

${ }^{39}$ Recurso Extraordinário n. 158.655. Relator Ministro Marco Aurélio Mello. Segunda Turma. Brasília, 20 de agosto de 1996. Diário da Justiça, 2 maio 1997, p. 16.567.

${ }^{40}$ FREITAS, Juarez. A interpretação sistemática do Direito. 3. ed. São Paulo: Malheiros, 2002. p. 196.

${ }^{41}$ A crítica que aqui se faz à atuação do Supremo Tribunal Federal, que, por vezes, tem declinado de seu papel primordial de guardião da Constituição, possui um foco principal: não se pode deixar ao alvitre dos Tribunais locais a determinação, através da devida motivação explicitada dos votos, ou não, de quando será, ou não, conhecido o recurso extraordinário. Tamanho formalismo por parte do Pretório Excelso ocasiona excelentes resultados no que diz respeito ao acúmulo de serviço, que é atenuado; porém, se analisado sob o panorama do sistema judiciário, conclui-se que ele é causa de uma séria subversão da ordem constitucional: o Tribunal de origem pode controlar, através da redação empregada no acórdão, de certo modo, a reforma, ou não, de seus próprios julgados.

${ }^{42}$ CARNEIRO, Athos Gusmão. Recurso especial, agravos e agravo interno. 3. ed. Rio de Janeiro: Forense, 2003. p. 36.

${ }^{43}$ CANOTILHO, José Joaquim Gomes. Constituição Dirigente e Vinculação do Legislador. 2. ed. Coimbra: Coimbra, 2001. p. 363. JORGE MIRANDA, por outro lado, com acerto incomum afirma: "A garantia da Constituição revela- 
nos o Direito constitucional: vamos ver que justamente o actual estádio do Direito constitucional leva consigo uma fase de busca de garantia da Constituição, em confronto com uma fase anterior em que se descobre na própria Constituição a garantia." (MIRANDA, Jorge. Contributo para uma teoria da inconstitucionalidade. Reimpressão. Coimbra: Coimbra Editora, 1996. p. 14)

${ }^{44}$ Bem disserta JUAREZ FREITAS: "De outra parte, se se apresenta seguro que o intérprete lúcido viabiliza a flexibilidade do sistema, não se mostra menos seguro que o sistema precisa de partes cuja rigidez há de ser preservada, sendo este um motivo a mais para que a inafastabilidade do acesso ao Judiciário seja encarecidamente resguardada, eis que se trata de princípio fundamental e intangível em nosso sistema. Fora desses moldes a Carta corre o risco de perecer, afetada em sua medula. (...) Ora, uma vez que o juiz figura como detentor único da jurisdição própria, daí surge o amplo e irrenunciável direito de acesso à tutela jurisdicional como espécie de contrapartida lógica, devendo ser proclamado este vetor decisivo no processo de interpretação constitucional: na dúvida, prefira-se a exegese que amplia o acesso ao Poder Judiciário, por mais congestionado que se encontre, sem embargo de providências inteligentes para desafogá-lo, sobretudo coibindo manobras recursais protelatórias e assumidas as precípuas tarefas de controle da constitucionalidade." (FREITAS, Juarez. A interpretação sistemática do Direito. 3. ed. São Paulo: Malheiros, 2002. pp. 196/197)

${ }^{45}$ Cf. JOSÉ JOAQUIM GOMES CANOTILHO, Direito Constitucional..., pp. 651/ 652. 